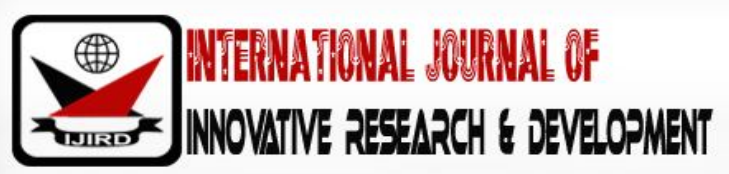

ISSN 2278 - 0211 (Online)

\section{Exploring the Multi-Dimensional Effect of Intrinsic Motivation among Pre-Service Teachers on Gender}

\author{
Mohammed Nurudeen Alhassan \\ Mathematics Tutor, Department of Mathematics \& ICT, OLA College of Education, Ghana \\ Jonathan A. Fletcher \\ Professor, School of Education and Leadership, University of Ghana, Ghana
}

\begin{abstract}
:
The study exploring the multi-dimensional effect of intrinsic motivation among pre-service teachers by gender. This was done to determine whether Pre-service teachers differed on their Intrinsic Motivation. The IMOT adapted from the Intrinsic Motivation Inventory was to collect data from pre-service teachers. A convenient sample of 89 pre-service teachers, made up of 77 male and 12 female were used. A multiple linear regression conducted, showed that only students' perceived interest is the only predictor of mathematics achievement. That means that students who demonstrate high levels of interest in the study of mathematics are more likely to succeed in it. It is important to employ all means possible to develop students' interest in mathematics as it appears to be the one of the driven force for students' mathematics achievement.
\end{abstract}

Keywords: Pre-service teachers, gender, self determination theory, motivation, multi-dimensional

\section{Introduction}

The motivation to take Mathematics course in the university is a complex phenomenon and is often associated with numerous reasons and different types of motivation (Pelletier et al., 2013). Understanding of motivation in the study of mathematics is indispensable because it appears to be hook that engages and keeps a person in it. Therefore, an examination of how different types of motivation (i.e., intrinsic vs. extrinsic) are associated with mathematics engagement is highly necessary for sustaining interest.

Research studies have often incorporated the self-determination theory (SDT) framework to engagement areas of study (Pelletier et al., 2013). The SDT has it that individuals persistently attempt to control their own social environments to master some basic psychological needs, which includes but not limited to perceived Interest, perceived competence, perceived usefulness, perceived anxiety and perceived effort. In accordance with Intrinsic Motivation Inventory (IMI) these five dimensions were considered as predictor variables of intrinsic motivation.

Perceived interest to cognitive-evaluation and self-determination theory, predictors of intrinsic motivation are personal preferences of activities and the competence those individuals feel while engaging in those activities are the driving force behind the activities. Proponents of the theory posts that when activities are perceived as chosen (i.e., self-determined) rather than required, and when people believe personal success in the activities, there is a high likelihood that intrinsic motivation is experienced in the form of interest.

Zimmerman (2000) acknowledged that Perceived competence is students' belief that their academic capabilities play a key role in achievement motivation. Beliefs about perceived competence, play in motivating students is the primary focus of several theoretical perspectives (Pajares, 1996). Perceived competence represents the extent to which a person believes that he or she has performed or is able to perform well at an activity (Bandura, 1982; Harter, 1981). It is often noted to affect intrinsic motivation following feedback, either during or at the conclusion of performance on a task (Bandura, 1982; Harackiewicz, 1989).

In this research anxiety and pressure is used interchangeably to mean a kind of special apprehension formed in learning and applying mathematics. It influences the efficiency and effect of a student input and output strategies in mathematics task. Individuals, who perceive mathematics as difficult and their ability to do mathematics as poor, generally avoid mathematics, if possible (Hilton, 1981; Otten \& Kuyper, 1988). Such students are described as mathematically anxious (Middleton, \& Spanias, 1999).

Fennema and Sherman (1976) incorporated perceived usefulness into their Mathematics Attitude Scales, and researchers have used these and other scales to demonstrate that perceived usefulness is consistently related to mathematics performance. Utility value is considered mean the degree to which students' value mathematics for its usefulness in a 
purposeful or industrious undertaking, especially one that requires effort or boldness. Eccles and Wigfeild (1995) found that students' choice to participate in a mathematics task related to their valuing of mathematics. This means to choose to study mathematics other than another subject, demonstrate one's way of saying that mathematics is useful.

Perceived effort is important for students to learn how to learn and take control of their efforts towards the study of mathematics. One self-regulatory resource management strategy described by Pintrich, Smith, Garcia, and McKeachie (1991) is effort regulation. It is sometimes referred to as volition (Corno, 1993). Effort regulation refers to a learner's ability to control his or her attention and efforts even in distractions situations. This is a clear demonstration of intrinsic motivation, as those distractions are not enabling enough to disengage the person's commitment to complete study goals in mathematics. A person's ability to manage her or his effort is important to academic success in mathematics, because it not only does it signify goal commitment, but regulates the continued use of learning moves in task accomplishment (Pintrich, Smith, Garcia \& McKeachie, 1991). The perception of competence refers to the opportunity to express one's own capability of physical or mental prowess or psychological well-being,. Autonomy is related to the ability to act or express oneself in ways that match one's own needs and value system (Deci and Ryan, 1985).

Research studies that consider differences in academic achievement have often demonstrated an advantage for female students over males (Voyer \& Voyer, 2014). This advantage of females expands to various educational levels and institutions, including university settings (Conger \& Long, 2010). Cognitive ability is not noted explain gender differences in achievement by share presence of similar patterns in Intelligent quotient scores in male and female students (Gibb, Fergusson \& Horwood, 2008). This suggests that disparities in achievement between males and females could be attributed to alternative factors.

Some researchers (e.g. Kange the, Lyria \& Nyamanga, 2014; Brady \& Eisler, 1995; Frawley, 2005) have attributed environmental or contextual factors to explain gender differences in achievement. These factors include socialization, gender biases in teaching in assessment (Woodfield, 2005). Although these factors are genuine, other internal factors, such as academic motivation could lead to behaviours such as increased study time, which could have significant implications for male and female students to build the necessary skills and knowledge to mathematics achievement. Indeed, the importance of motivation in academic performance has been revealed in studies among students of different cultural background (Ginsberg, 2005), at various levels in academic career (Ivankova \& Stick, 2007; Lovitts, 2001; Martin, 2009), and of different sexes (Meece, Glienke \& Burg, 2006; Velayutham, Aldridge \& Fraser, 2012).

According to the self-determination theory (SDT) posited by Ryan and Deci, (2009), intrinsic motivators produce more positive academic outcomes than external regulators. Consequently, in order to determine how the dimensions, vary in term of gender more research is needed. Research has it that gender differences are apparent within intrinsic (McGeown, Goodwin, Henderson \& Wright, 2012) and extrinsic (Rusillo, Teresa, Arias, \& Felix, 2004) attributes, learning strategies (Massachi, 2000), self-efficacy (Pajares \& Valiante, 2001), and hours devoted to studying (Trautwein \& Ludtke, 2007). Although gender differences in academic motivation are evident in lower levels of education (Hornstra, van der Veen, Peetsma, \& Volman, 2013; Vecchione, Alessandri \& Marsciano, 2014), research conducted in schools may lack the impetus to extend to a university environment, because these groups of students have chosen to study mathematics at the highest level and may exhibit higher levels of motivation (Pintrich, 2003).

More so empirical investigations in higher education context revealed inconsistent results. Whilst some studies on measuring self-efficacy and using a mixed subject-area student used for the study showed that males retain higher levels of academic self-efficacy (Shkullaku, 2013; D’Lima, Winsler \& Kitsantas, 2014). Other research studies revealed the opposite (Chavez, Beltran, Guerrero, Enriquez \& Reyes, 2014). The inconsistencies were also reported in studies concentrating on intrinsic and extrinsic motivation (e.g., Brouse, Basch, LeBlanc, McKnight, \& Lei, 2010; Hakan \& Munire, 2014; Vallerand \& Bissonnette, 1992). More so no significant effect of gender was found on active participation learning strategies (Davidson et al., 2014; Severiens \& Ten Dam, 1994; Tarabashkina and Lietz, 2011). In addition, Becker and Ulstad (2007) as well as Drewes (2009) puts female undergraduates to have devoted more time to self-regulated learning than males. Given that male and female students differ in the amount of time spent on studying, it may well be that certain factors could be predicting mathematics achievement to a different extent for the two genders. This supposition needs to be tested. Variations between the genders in terms of the predictive value of intrinsic and extrinsic motivational attributes on achievement have been demonstrated within literature.

Cortright, Lujan, Blumberg, Cox and DiCarlo (2013) reported significant academic achievement for male, but not for female students on intrinsic motivation. This however, was limited in the extent to which it could be generalized because of small sample size, and specifically focused on physiology students. In another study with 419 Italian students, Vecchione et al. (2014) revealed that that the predictive value of intrinsic motivation on academic outcome appeared to favour females, whereas the impact of extrinsic motivation was more favorable for males. However, given the paucity of studies in the area, research with pres-service teachers is warranted in Ghana as males continued to dominate females in numerical strength.

Further, Robbins et al. (2004) meta-analytic study revealed that achievement motivation (both intrinsic and extrinsic) in general is a significant predictor of students' grade point average; self-efficacy was reported to be the best predictor of both grade point average and academic persistence. In another study by Turner, Chandler, and Heffer (2009), self-efficacy and intrinsic motivation scores were positively correlated with academic performance. Similar result by Hannon (2014) found that self-efficacy, epistemic belief of learning, and high-knowledge integration could have explained up to about $23 \%$ of variance in grade point average in a sample of freshmen and Non-freshmen. Despite the contradictions in the literature, the multi- 
dimensions of intrinsic motivation on gender appeared to be less studied, hence the need explore it in a Ghanaian university among pre-service teachers in their initial training years.

\section{Materials and Methods}

The survey design was used for the study. In all 89 students were selected by convenience in view of the small number of students who were admitted for the academic year. These were made up 12 females and 77 males. A 20 item Likert Scale questionnaire was administered to the 89 pre-service teachers offering Bachelor of Education mathematics option. This instrument measures pre-service teacher intrinsic motivation using dimensions perceived interest, usefulness, competence and effort. The pre-service teachers were required to complete the questionnaire which lasted for about 25minutes. The data was entered into SPSS software and analysis was run. After a series of factor analysis, all constructs showed significant loadings from .356 to .876 on 3 to 4 items, except the perceived anxiety sub-scale with only 2 significant item loadings and was subsequently dropped given way to 13 items. The scale reliabilities for the thirteen (13) item intrinsic motivation questionnaire was .73. The internal consistency alpha coefficients ranged from .75 to .79 and were satisfactory on the basis of Nunnally's (1978) and McMillan and Schumacher (2006) criterion of a minimum of .70.

\section{Theory/ Calculation}

Ryan, Kuhl and Deci (as cited in Areepattamannil and Freeman 2008), SDT is an approach to human motivation that highlights the importance of the psychological need for autonomy. This implies that individuals experience choice in an act that sets in motion some course of events, maintenance, and regulation of their behaviours (Deci \& Ryan, 2000). To choose to engage in an activity rather than being required to perform it in order to satisfy the expectations or demands of others shows how intrinsically motivated a person is. The internal drive to study mathematics at the highest level is the motivation behind the current study to determine if males and females differ in terms of intrinsic motivation.

The Independent-Samples t-test procedure is used to compare two groups in a population. The independent-samples $t$ tests also test hypotheses about differences between two means. However, the means should be from the same variables, but for two different populations which makes it fit the current study. The differences in the mean dimensional ratings of male and female pre-service teacher on four constructs are examined.

\section{Results and Discussion}

The hypothesis that guided the study was 'there is no significant difference between the mean dimensional ratings of male and female' pre-service teachers. This was designed to find if significant differences exist in the ratings between the sexes.

\subsection{Descriptive Statistics of the Sample}

Table shows that the item rating is higher in males than in the females; however, the deviations in the mean rating of the males are also showing higher variations, but lower errors in the ratings. This scenario could be attributable to the sharp differences in sample size. The females appeared to have committed marginal errors in terms the distribution of their scores.

\begin{tabular}{|c|c|c|c|c|c|}
\hline & $\begin{array}{c}\text { Respondent's } \\
\text { Sex }\end{array}$ & $\mathbf{N}$ & Mean & $\begin{array}{c}\text { Std. } \\
\text { Deviation }\end{array}$ & $\begin{array}{c}\text { Std. Error } \\
\text { Mean }\end{array}$ \\
\hline $\begin{array}{c}\text { Perceived interest } \\
\text { in mathematics }\end{array}$ & Male & 77 & 4.33 & 0.780 & .089 \\
\cline { 2 - 6 } & Female & 12 & 4.25 & 0.566 & .164 \\
\hline $\begin{array}{c}\text { Perceived } \\
\text { usefulness } \\
\text { of mathematics }\end{array}$ & Male & 77 & 4.65 & 0.614 & .070 \\
\hline \multirow{2}{*}{$\begin{array}{c}\text { Perceived } \\
\text { competence } \\
\text { in mathematics }\end{array}$} & Memale & 12 & 4.58 & 0.405 & .117 \\
\cline { 2 - 6 } & Female & 77 & 3.04 & 1.192 & .136 \\
\hline $\begin{array}{c}\text { Perceived effort in } \\
\text { the study } \\
\text { of mathematics }\end{array}$ & Male & 77 & 4.07 & 0.883 & .221 \\
\cline { 2 - 6 } & Female & 12 & 4.00 & 1.107 & .138 \\
\hline
\end{tabular}

Table 1: Descriptive Statistics of the Sample by Gender

To respond to the hypothesis, an independent sample t-test was conducted and the result is presented in Table 1 . The results revealed no significant differences in the four variables: perceived interest, perceived competence, perceived usefulness and perceived effort in mathematics. For perceived interest(male: $\mathrm{M}=4.33$, $\mathrm{SD}=.780$; female: $\mathrm{M}=4.25, \mathrm{SD}=.566$; $\mathrm{t}$ $(87)=.326, p>.05$, perceived usefulness (male: $\mathrm{M}=4.65, \mathrm{SD}=.614$; female: $\mathrm{M}=4.58, \mathrm{SD}=.405 ; \mathrm{t}(87)=.360, \mathrm{p}>.05$, perceived competence (male: $\mathrm{M}=3.04$, $\mathrm{SD}=1.192$; female: $\mathrm{M}=2.76$, $\mathrm{SD}=.767$; $\mathrm{t}(87)=.785$, $\mathrm{p}>.05$, perceived effort (male: $\mathrm{M}=4.07, \mathrm{SD}$ $=.883$; female: $\mathrm{M}=4.01, \mathrm{SD}=1.107 ; \mathrm{t}(87)=.229$, $\mathrm{p}>.05$. 


\begin{tabular}{|c|c|c|c|c|c|c|}
\hline \multicolumn{7}{|c|}{ Levene's Test for Equality of Variances } \\
\hline & & F & Sig & t & Df & Sig.(2-tailed) \\
\hline $\begin{array}{c}\text { Perceived interest in } \\
\text { mathematics }\end{array}$ & Equal variances assumed & .481 & .490 & .326 & 87 & .745 \\
\hline $\begin{array}{c}\text { Perceived usefulness of } \\
\text { mathematics }\end{array}$ & Equal variances assumed & .223 & .638 & .360 & 87 & .720 \\
\hline $\begin{array}{c}\text { Perceived competence } \\
\text { in mathematics }\end{array}$ & Equal variances assumed & 5.956 & .067 & .785 & 87 & .295 \\
\hline $\begin{array}{c}\text { Perceived effort in } \\
\text { the study } \\
\text { of mathematics }\end{array}$ & Equal variances assumed & 3.534 & .064 & .229 & 87 & .820 \\
\hline
\end{tabular}

Table 2: Independent Sample T-Test for Gender Differences in Dimensions of Intrinsic Motivation

As shown in Table 2, no significant difference was found among all variables. As such, the nature of differences was not determined. The result showed that females and males did not differ in the dimensions, and as such both sexes viewed mathematics as useful, perhaps see themselves as competent, have developed positive interest in mathematics and are willing to put in more effort to succeed in mathematics. This result agrees with Gottfried (1990) when he concluded that there was no gender difference in intrinsic motivation for mathematics, even though the multi-dimensions of intrinsic motivation was used for this work. Once students are admitted, irrespective of their gender they are both on equal footings to start learning mathematics and to be successful in it.

\section{Conclusion}

The research found no significant difference between the mean dimensional ratings of male and female' pre-service teachers. This means the current gender parity that exists could be bridged by increasing the numbers of female applicants in the university.

\section{References}

i. Areepattamannil, S., \& Freeman, J. G. (2008). Academic achievement, academic self-concept, and academic motivation of immigrant adolescents in the Greater Toronto Area Secondary Schools. Journal of Advanced Academics, 19(4), 700 743.

ii. Bandura, A, (1982). Self-efficacy mechanism in human agency. American Psychologist 37, 122-147.

iii. Becker, D. A. \& Ulstad, I. (2007). Gender Differences in Student Ethics: Are Females Really More Ethical? Plagiary: Cross-Disciplinary Studies in Plagiarism, Fabrication, and Falsification, 1 (1), 77-91.

iv. Brady, K. L. \& Eisler, R. M. (1995). Gender Bias in the College Classroom: A Critical Review of the Literature and Implications for Future Research. Journal of Research and Development in Education, 29(1), 9-19.

v. Brouse, C. H., Basch, C. E., LeBlanc, M., McKnight, K. R., \& Lei, T. (2010). College students' academic motivation: Differences by gender, class, and source of payment. College Quarterly, 13 (1), 1-10.

vi. Chavez, J. F. A., Beltran, F. M., Guerrero, A.C., Enriquez, M. C. Z., \& Reyes, J. J. (2014) . A gender study on college students' academic self-efficacy. Science Journal of Education, 2 (6), 180-184.

vii. Conger, D., \& Long, M. C. (2010). Why Are Men Falling Behind? Gender Gaps in College Performance and Persistence. The ANNALS of the American Academy of Political and Social Science, 627 (1), 184-214.

viii. Cortright, R. N., Lujan, H. L., Blumberg, A. J., Cox, J. H., \& DiCarlo, S. E. (2013). Higher levels of intrinsic motivation are related to higher levels of class performance for male but not female students. Advances in Physiology Education, 37 (3), 227-232.

ix. Davidson, P., Roslan, S., Abdullah, M. C., Omar, Z., Chew, S. C., Hussein, H., \& Neik, T.T.X. (2014). Gender and course differences in students approaches to learning: do they really exist?. In 8th International Technology, Education and Development Conference, Retrieved from http:/ library.iated.org/ view/ DAVIDSON2014GEN.

x. D'Lima, G. M., Winsler, A., \& Kitsantas, A. (2014). Ethnic and gender differences in first year college students' goal orientation, self-efficacy and extrinsic and intrinsic motivation. The Journal of Educational Research, 107 (5), 341-356.

xi. Deci, E. L., \& Ryan, R. M. (1985). Intrinsic motivation and self-determination theory of human behaviour. New York: Plenum.

xii. Deci, E. L., \& Ryan, R. M. (2000). The "what" and "why" of goal pursuits: Human needs and the self- determination of behaviour. Psychological Inquiry, 11, 227-268.

xiii. Eccles, J. S., \& Wig field, A. (1995). In the mind of the actor: the structure of adolescents' achievement task values and expectancy-related beliefs. Personality and Social Psychology Bulletin, 21(3), 215-225.

xiv. Fennema, E., \& Sherman, J. (1976). Sex-related differences in mathematics learning: Myths, realities, and related factors. Paper presented at the annual meeting of the American Association for the Advancement of Science, Boston.

xv. Frawley, T. (2005). Gender bias in the classroom: current controversies and implications for teachers. Childhood Education, 81(4), 221-227. 
xvi. Gibb, S. J., Fergusson, D. M., \& Horwood, L. J. (2008). Gender differences in educational achievement to age 25. Australian Journal of Education, 52 (1), 63-80.

xvii. Ginsberg, M. B. (2005). Cultural diversity, motivation, and differentiation. Theory into Practice, 44 (3), 218-225.

xviii. Hakan, K. \& Munire, E. (2014). Academic motivation: Gender, domain and grade differences. Procedia - Social and Behavioural Sciences, 143 (1), 708-715.

xix. Harackiewicz, J. M. (1989). Performance evaluation and intrinsic motivation processes: The effects of achievement orientation and rewards. In D. M. Buss \& N. Cantor (Eds.), Personality psychology: Recent trend and emerging directions (pp. 128-137). New York: Springer-Verlag.

xx. Harter, S. (1981). A new self-report scale of intrinsic versus extrinsic orientation in the classroom: Motivational and informational components. Developmental Psychology, 17, 300-312.

xxi. Hilton, P. J. (1981). Avoiding math avoidance. In L. A. Steen (Ed.), Mathematics tomorrow (pp. 73-82). New York: Springer-Verlag.

xxii. Hornstra, L., van der Veen, I., Peetsma, T., \& Volman, M. (2013). Developments in motivation and achievement during primary school: A longitudinal study on groupspecific differences. Learning and Individual Differences, 23, 195-204.

xxiii. Ivankova, N., \& Stick, S. (2007). Students' persistence in a distributed doctoral program in educational leadership in higher education: A mixed methods study. Research in Higher Education, 48, 93-135.

xxiv. Kangethe, N. S., Lyria, K. S., \& Nyamanga, A. M. (2014). The gender socialization question in education: influence on boys' and girls' academic achievement. European Scientific Journal, 10(19), 279-294.

xxv. Lovitts, B. E. (2001). Leaving the ivory tower: The causes and consequences of departure from doctoral study. New York, NY: Rowman \& Littlefield.

xxvi. Martin, A. J. (2009). Motivation and engagement across the academic life span: A developmental construct validity study of elementary school, high school, and university/college students. Educational and Psychological Measurement, 69 (5), 794-824.

xxvii. Massachi, Y. (2000). A cross culture comparison of learning styles (Masters Graduate Thesis). Retrieved from http:/ / scholarworks.rit.edu/ cgi/ viewcontent.cgi?article=2357\&context=theses.

xxviii. McGeown, S., Goodwin, H., Henderson, N., \& Wright, P. (2012). Gender differences in reading motivation: does sex or gender identity provide a better account?. Journal of Research in Reading, 35 (3), 328-336.

xxix. McMillan, J. H., \& Schumacher, S. (2006). Research in education: Evidence-based inquiry (6th ed.). Boston: Pearson.

xxx. Meece, J. L., Glienke, B. B., \& Burg, S. (2006). Gender and motivation. Journal of School Psychology, 44 (5), 351-373.

xxxi. Middleton, J. A, \& Spanias, P. A. (1999). Motivation for Achievement in Mathematics: Findings, Generalizations, and Criticisms of the Research. Journal for Research in Mathematics Education, 30(1), 65-88.

xxxii. Nunnally, J. C. (1978). Psychometric theory. New York: McGraw-Hill.

xxxiii. Otten, W., \& Kuyper, H. (1988). Gender and mathematics: The prediction of choice and achievement. In A. Bourbás (Ed.), Proceedings of the twelfth annual conference of the International Group for the Psychology of Mathematics Education, (Vol. 2, pp. 519-527). Veszprém, Hungary: Hungarian National Centre for Educational Technology.

xxxiv. Pajares, F. (1996). Self-efficacy beliefs in achievement settings. Review of Educational Research, 66, 543-578.

xxxv. Pajares, F. \& Valiante, G. (2001). Gender differences in writing motivation and achievement of middle school students: A function of gender orientation?. Contemporary Educational Psychology, 26 (3), 366-381.

xxxvi. Pelletier L.G., Fortier M.S., Vallerand R.J., Tuson K.M., Briere N.M., \& Blais, M.R. (2013) Toward a new measure of intrinsic motivation, extrinsic motivation, and amotivation in sports: The Sport Motivation Scale (SMS). J Sport Exer Psy, 1995; 17: 35-53

xxxvii. Pintrich, P. R., Smith, D. A. F., Garcia, T., \& McKeachie, W. J. (1991). A manual for the use of the Motivated Strategies for Learning Questionnaire (MSLQ). MI: National Center for Research to Improve Postsecondary Teaching and Learning. Retrieved from ERICDatabase. (ED 338 122)

xxxviii. Pintrich, P. R., Smith, D. A., Garcia, T., \& McKeachie, W. J. (1993). Reliability and predictive validity of the Motivated Strategies for Learning Questionnaire (MSLQ). Educational and Psychological Measurement, 53(3), 801-813.

xxxix. Robbins, S. B., Lauver, K., Le, H., Davis, D., Langley, R., \& Carlstrom, A. (2004). Do psychosocial and study skill factors predict college outcomes? A meta-analysis. Psychological Bulletin, 130 (2), 261-288.

xl. Ryan, R. M., \& Deci, E. L. (2009). Promoting self-determined school engagement: Motivation, learning, and well-being. In K. R. Wentzel, \& A.Wigfield (Eds.), Handbook on motivation at school (pp. 171-196). New York, NY: Routledge

xli. Severiens, S. E. \& Ten Dam, G. T. M. (1994). Gender differences in learning styles: A narrative review and quantitative meta-analysis. Higher Education, 27 (1), 487-501.

xlii. Shkullaku, R. (2013). The relationship between self-efficacy and academic performance in the context of gender among Albanian students. European Academic Research, 1 (4), 467-478.

xliii. Tarabashkina, L. \& Lietz, P. (2011). The impact of values and learning approaches on student achievement: Gender and academic discipline influences. Issues in Educational Research, 21 (2), 210-231.

xliv. Trautwein, U. \& Ludtke, G. (2007). Students' self-reported effort and time on homework in six school subjects: Between-students differences and within-student variation. Journal of Educational Psychology, 99 (2), 432-444. 
xlv. Turner, E. A., Chandler, M., \& Heffer, R. W. (2009). The influence of parenting styles, achievement motivation, and selfefficacy on academic performance in college students. Journal of College Student Development, 50 (3), 337-346.

xlvi. Vallerand, RJ. \& Bissonnette, R. (1992). Intrinsic, extrinsic, and amotivational styles as predictors of behavior: A prospective study. Journal of Personality, 60(3), 599-620.

xlvii. Vecchione, M., Alessandri, G., \& Marsicano, G. (2014). Academic motivation predicts educational attaintment: Does gender make a difference. Learning and Individual Differences, 32 (1), 124-131.

xlviii. Velayutham, S., Aldridge, J. M., \& Fraser, B. (2012). Gender differences in student motivation and self-regulation in science learning: a multi-group structural equation modeling analysis. Journal of School Psychology, 10 (6), 13471368.

xlix. Voyer, D. \& Voyer, S.D. (2014). Gender differences in scholastic achievement: A metaanalysis. Psychological Bulletin, $140(4), 1174-1204$.

l. Woodfield, R. (2005). Gender and mode of assessment at university: should we assume female students are better suited to coursework and males to unseen examinations? Assessment \& Evaluation in Higher Education, 30(1), 35-50.

li. Zimmerman B J (2000) Self-regulatory cycles of learning. In G A Straka (Ed.), Conceptions of self-directed learning, theoretical and conceptual considerations. New York, Waxman (pp. 221-234). 